\title{
LOGISTICS SECTOR IN AZERBAIJAN ECONOMY: STRUCTURAL IMPROVEMENTS AND ORIENTATIONS STRATEGIC DEVELOPMENT
}

\author{
Elshad Masim oghlu Yusifov \\ Department of Service areas Economics and Management \\ Azerbaijan University of Architecture and Construction \\ 11 A. Sultanova str., Baku, Azerbaijan, AZ1073 \\ elshadyusifov1977@gmail.com \\ Tekmez Korkmaz oghlu Kulu \\ Celal Bayar University Ahmetli Professional Schol \\ 4 Demirciler Cd., Güldede Mahallesi, Manisa, Turkey, 45450 \\ tekmez35@hotmail.com
}

Hasan Parviz oghlu Mammadov

$P h D$

hasanmammadov80@gmail.com

\begin{abstract}
The article focuses on the current state of the logistics sector in Azerbaijan and the prospects for its development. In this regard, the article assesses the role of logistics in the development of the country's economy, as a sphere of non-oil sector. It is noted, that the geographical position of Azerbaijan allows the regular increase of trade volumes. The development of trade depends on the development of the logistics sector. According to statistical data on the transport sector of the State Statistical Committee of Azerbaijan, the dynamics of cargo transportation and passenger transportation on the rail, offshore, highways and airways in the country are analyzed and the situation for the last eight years is assessed.

The role of main pipelines and international transport corridors in the economic development of Azerbaijan is also appreciated. Azerbaijan joins these transport corridors as an interregional transit center. It is shown, that those main pipelines and international transport corridors will serve not only the distribution of Azerbaijan, but also the economies of the region and the European countries. It will also contribute to the formation of competitive markets and will continue to maintain its relevance for a long time.

Based on the Strategic Roadmap for the development of logistics and trade in Azerbaijan Republic, the SWOT analysis of the logistics sector has been given in the country and has shown the perspective strengths that will contribute to the economic development. Also highlighted are the weaknesses that are important to improve. The possibilities of this area and the dangers that may arise are investigated. Strategic considerations and targets for the development of the logistics sector in Azerbaijan by 2020 and 2025, as well as after 2025 are assessed, the importance of the role of the implemented and planned projects in the development of the economy of the country, the region, and in the economy of the strategic partner countries is substantiated. The article identifies existing problems to achieve strategic goals in this area, and suggests ways to optimize them.

Keywords: logistics sector, railway transport, maritime transport, motorway, airway, magistral pipelines, international transit corridors, strategic targets.

\section{Introduction}

Logistics and trade play a key role in the development of all sectors and play an important role in creating value added and new jobs and increasing profitability. Value-added services will be provided to integrate into the regional and global value chains in the field of logistics, as well as to generate high returns from transit trading, based on the best practices in the world. The geographical position of Azerbaijan allows the regular increase of trade volumes. The continuous development of the country's logistics assets will boost its role in regional and international trade. Thanks to its favorable geographical position on both the East-West corridor, the North-West and the North-South Corridor, our country has the ability to receive transit trade and import-export 
operations. A number of important infrastructure projects related to the new ports and railways have already been completed. Taking into consideration these assets and advantages, a number of initiatives will be undertaken to increase the volume of trade through the creation of intermodal and multimodal logistics infrastructures in Azerbaijan, with the aim of gaining more value from transit trade and increasing the private sector participation in logistics.

The unstable oil prices in the oil sector, which began in 2014, had shown that the development of the non-oil sector in Azerbaijan is a must. As a result of the reforms, the transport sector was selected as part of the non-oil sector development. As a confirmation of this, the Decree of the President of the Republic of Azerbaijan, dated December 6, 2016, "Strategic Roadmap for development of logistics and trade in the Republic of Azerbaijan" was adopted for the development of the transport sector.

A number of experts have examined the specific features of the development of the logistics sector. Consequently, the efficiency and reliability of the logistics system affects economic productivity which is the most important determinant of economic performance. Therefore, logistics industry is the artery and the basic industry of the national economic development in the world. Its development level is one of the important marks to evaluate the level of state modernization and comprehensive national strength.

Logistics is the accelerator of the economic development and growth [1].

The logistics sector appears as the most important development factor in sustainable maintenance of the regional development [2].

Better transport may encourage start-ups and survival by lowering costs, or allowing firms to take advantage of increasing returns to scale or agglomeration economies [3].

Climatic conditions during the development of logistics industry should also be considered. Once a more detailed risk assessment is made, different adaptation measures can be investigated, some of them being applied specifically to transport infrastructure, others requiring a cross-cutting assessment including long term land use planning [4].

Thus, in the economic literature, many studies have been carried out to study the relevant field, but little attention has been paid to the economic development of individual countries. From this point of view, it is important to study the importance of logistics in the Azerbaijani economy.

\section{Aim of research}

The main aim of the research is to analyze the role of the logistics sector in the economy of Azerbaijan and assess the strategic aspects of the development of the sector.

\section{Materials and Methods}

"Strategic Roadmap for development of logistics and trade in the Republic of Azerbaijan" (the Strategic Roadmap) was developed as an integral part of the initiatives of a competitive, diversified, inclusive and sustainable economy. This Strategic Roadmap sets short, medium and long-term perspective directions for the economic development in logistics and trade in Azerbaijan until 2020, 2025 and after 2025. The priorities for this area have been selected to achieve these goals and targets.

As a result of these measures, the real GDP of the Republic of Azerbaijan will increase by 605 million manats in 2020, and 18900 new jobs will be created in the country. It is expected, that 3 billion 160 million manats will be required from the state and private sources for the implementation of the planned measures.

With these measures it is planned to complete several projects in Azerbaijan by 2020. This includes the completion of the Baku Port complex, the Baku-Tbilisi-Kars railway, and Astara-Astara (Iran) railways. These projects will increase the number of full-time employees to up to 6700 by 2020 in Azerbaijan.

The share of freight services in total service exports in Azerbaijan has been about $10 \%$ in recent years. However, in some countries this figure varies between 8-52\%. International transportation is mainly carried out on the territory of Azerbaijan by rail. The volume of import and export operations in these transportations is high, but the volume of transit cargo, shipped to the intermediate point before delivery to the final destination, is relatively low [5]. 
According to the information of CJSC Azerbaijan Railways, 14.5 million tons of freight were transported by railway in 2017, of which 10.5 million tons were imported and exported, 4 million tons of domestic cargo, 3.3 million tons transit cargo. These indicators have decreased compared to previous years. Thus, if in 2010, 22.3 million tons of cargo were transported, in the year 2017, 14.5 million tons of cargo were transported (Fig. 1).

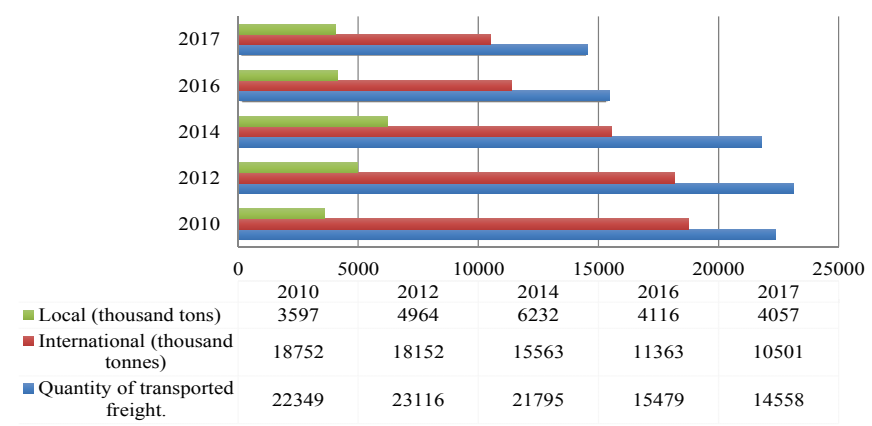

Fig. 1. Railway cargo transportation in Azerbaijan for 2010-2017.

Source: State Statistical Committee of the Republic of Azerbaijan. Azerbaijan Statistical Information Service. Statistics on transport sector. Baku 2018

Nevertheless, the revenues from transportation have increased relative to previous years. In 2010, the revenues from transportation amounted to 158.3 million manats, while in 2017 these figures were more than 200 million manats. It should be noted, that the figure exceeded 200 million in 2012 and reached 262 million manats in 2016. But in 2017 the revenue fell by $30 \%$ to 200 million manats. Average monthly nominal wages in the railway sector have increased 2 times, compared to the previous years and increased from 187.1 manats in 2010 to 367 manats in 2017. Thus, the share of transit cargo in the total volume of freight, transported from Azerbaijan by rail in 2015, was 22.9 percent. Passenger transportation has dropped, compared to 2010, and dropped from 4.8 million in 2010 to 2.5 million in 2017 (Fig. 2).

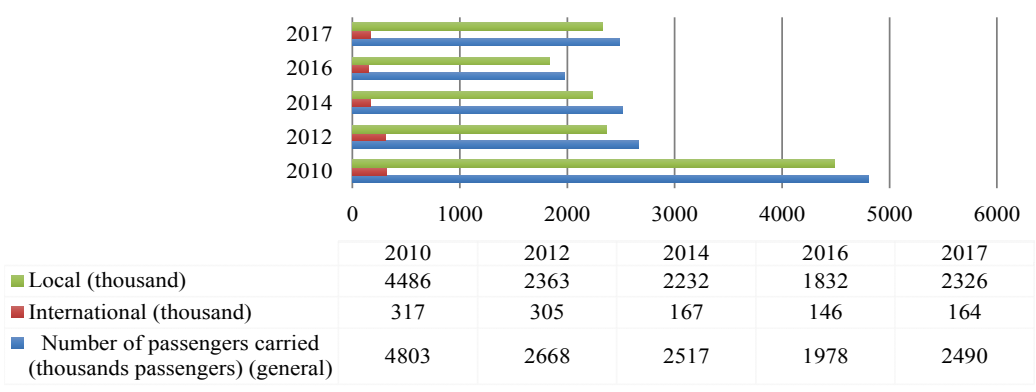

Fig. 2. Passenger transportation in railway transport in Azerbaijan for 2010-2017.

Source: State Statistical Committee of the Republic of Azerbaijan. Azerbaijan Statistical Information Service. Statistics on transport sector. Baku 2018

The number of freight wagons and containers, as well as the average annual number of employees, has declined. Also, since 2010 the number of freight and passenger carriages and containers has decreased from 18062, 719, 3036, to 9499, 213, 593 in 2017. The average annual number of employees dropped from 12,997 in 2010 to 7006 in 2017. However, average monthly nominal wages in the railway sector have increased 2 times, compared to the previous years and increased from 187.1 manats in 2010 to 367 manats in 2017.

The only city in the country with subway is Baku. The number of subway stations in Baku has increased from 22 in 2010 to 25 in 2017 . The total length is $36.6 \mathrm{~km}$. The number of passenger carriages increased from 251 to 280 units. Over the last few years, passenger traffic has increased. 
Thus, in 2010, 181 million people were transported and 228.8 million passengers were transported by 2017. At present, Baku Metro has 2 lines: Khatai- Darnagul and IcheriSheher - HaziAslanov lines. These lines are termed "Green Line" and "Red Line". In the Perspective Development Plan it is planned to create 3 new lines - "Purple", "Blue" and "Yellow". "Blue" line - New Yasamal Bakikhanov, "Purple" line - "Avtovaghzal" - Garachukhur, "Yellow" - Binagadi - Bibiheybat [6].

The length of railways in Azerbaijan from 2010 to 2017 has dropped from 2792 to $2481 \mathrm{~km}$. The total use has increased from $2079 \mathrm{~km}$ to $2132 \mathrm{~km}$. The electrified roads have decreased from $1251 \mathrm{~km}$ to $1224 \mathrm{~km}$. The length of unused roads has been reduced from $1251 \mathrm{~km}$ to $1224 \mathrm{~km}$. Taking into account the price of the ticket, the railroad still remains the most popular type of transport in the world. The train, which has a hundred miles of speed, is far behind the airplanes for its comfort. In Azerbaijan, railway transport had the capacity to carry 24 million passengers in its maximum time (1975). In 1990 this indicator dropped to 11.2 million, and in 1995 to 6.3 million. After one year, there has been a two-fold reduction. Between 1996 and 2009, these figures varied between 3-4 million passengers. In 2017 the result was 2.3 million. In recent years, the main reason for the decline in the population's use of railroad transportation in Azerbaijan is the lack of comfortable and fast trains. Another reason is the increase in people's personal vehicles. Starting from 2006, the exploitation period of trains in the country has begun. The security problem of passengers in railway transport has reached the highest level since 2015. The speed of old trains is $40-50 \mathrm{~km} / \mathrm{s}$, so it does not allow passengers to use these trains. Trains with speeds of up to $50 \mathrm{~km}$ per hour are a low indicator for the 21 st century. In developed countries this speed is $300-400 \mathrm{~km} / \mathrm{s}$.

It is necessary to build new railways to move modern and high-speed trains to the territory of Azerbaijan. Many of them require direct investments in their construction. However, for the objective reasons, the state can no longer undertake this obligation. On the other hand, the question of profitability is emerging. Azerbaijan is not such a big country. The longest railway line in the country is the Baku-Boyuk-Kesik railway and its length is $503 \mathrm{~km}$. If all these multi-billion investments are spent on building a high-speed rail system, the question arises: How much should the optimum cost of a ticket be? Because at least the costs should be reimbursed for technical maintenance of this system [7].

At the same time, transit cargo transportation in the Azerbaijani ports prevails. In 2017, the volume of goods, imported and exported by sea, amounted to 587,000 tons, and transit cargo volumes -6.8 million tons, representing 67.25 percent of total transit cargo. The number of shipped loads decreased, compared to 2010. Thus, if in 2010, 11.7 million tons of cargo was transported, 8.3 million tons of cargo were transported in 2017 (Fig. 3).

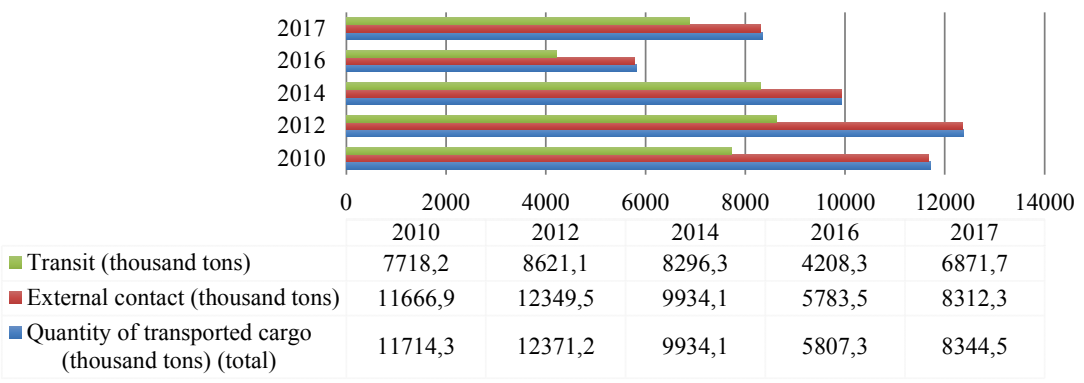

Fig. 3. Cargo transportation by sea in Azerbaijan for 2010-2017.

Source: State Statistical Committee of the Republic of Azerbaijan. Azerbaijan Statistical Information Service. Statistics on transport sector. Baku 2018

Most of the cargo, transported by sea was made up of coal, refined petroleum products, coke, mineral products, agricultural goods, and crude oils. At the same time, container shipments both on railways and at ports are relatively limited. Compared to previous years (2010), the revenues from offshore transportation have increased by $59.6 \%$ to 179.7 million manats in 2017 from 107.2 million manats (2010). 
Passenger transportation through sea transport increased from 12,000 in 2010 to 17,100 in 2012 and dropped by 14,700 in 2014. The highest figure was in 19,600 in 2016. In 2017, it dropped slightly and amounted to 17.1 thousand people (Fig. 4) [8].

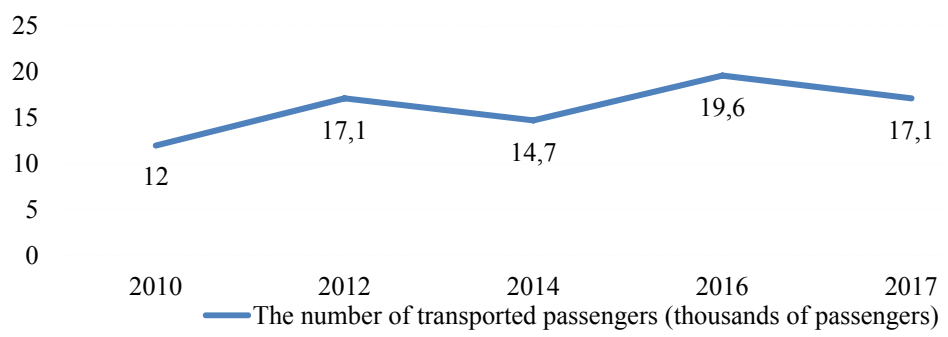

Fig. 4. Passenger transportation by sea in Azerbaijan for 2010-2017 (thousand passengers). Source: State Statistical Committee of the Republic of Azerbaijan. Azerbaijan Statistical Information Service. Statistics on transport sector. Baku 2018

In recent years, capital investments in the maritime transport sector have increased from 13.2 million manats in 2010 to 112.2 million manats by 2017. The number of ships has dropped from 80 to 50 units.

Automobile transport has been developed in Azerbaijan in recent years. In 2017, the proceeds from the transportation were around 1.3 billion manats. The revenues increased by 2 times, compared to 2010. Over the same years, cargo transplants have increased from 99.9 million tons in 2010 to 145 million tons in 2017 (Fig. 5) [8].

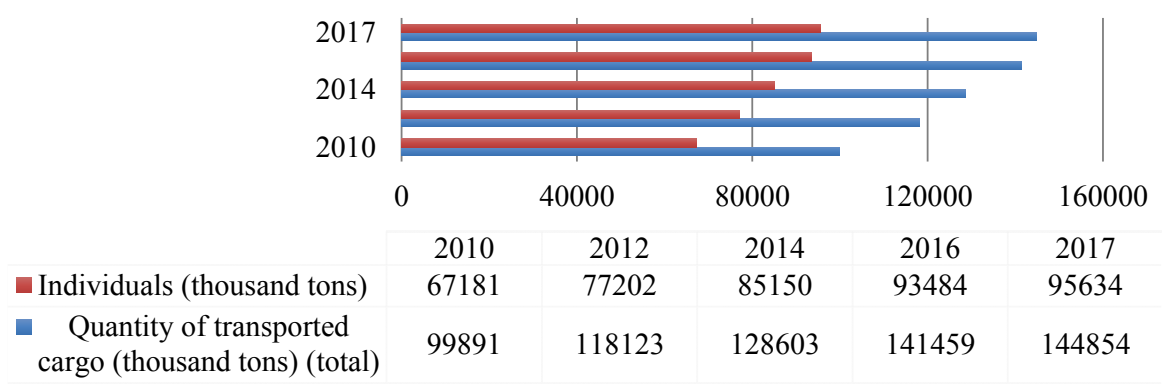

Fig. 5. Cargo transportation through Azerbaijan in 2010-2017 on car transport.

Source: State Statistical Committee of the Republic of Azerbaijan. Azerbaijan Statistical Information Service. Statistics on transport sector. Baku 2018

At the same time, there has been an increase in passenger transportation. From 1.2 billion in 2010 to 1.73 billion in 2017. These carriers will reach 50.365 million in 2017, an increase of 39.2 percent. 1,288 billion in urban traffic, an increase of 47.1 percent. In suburban transportation, the increase was $39,07 \%$ (Fig. 6), with 401,726 million increase.

The revenues from cargo transportation were 654 million manats in 2017. The expenses of passenger transportation for the same year were 348.5 million manats. As you can see, the cost of passenger transportation was more than the expenses. The average monthly nominal wage in the car transport sector increased from 382.7 manats in 2010 to 647.3 manats in 2017. The increase was $69.17 \%$. It should be noted, that in recent years, there has been a significant increase in the car transport sector in Azerbaijan. The total number of employees in this sector has increased from 13932 in 2010 to 22401 in 2017 . Over the years, the increase was 60.7 percent. The length of roads across the country is $19016 \mathrm{~km}$.

One of the emerging types of transport in recent years is air transport and there has been a significant increase in freight traffic. Thus, if 40 tons of cargo has been transported since 2010, this figure has reached 173 tons in 2017. The main cargo transportation was international cargo transportation and it comprised $98.84 \%$ of total shipments (Fig. 7) [8]. 


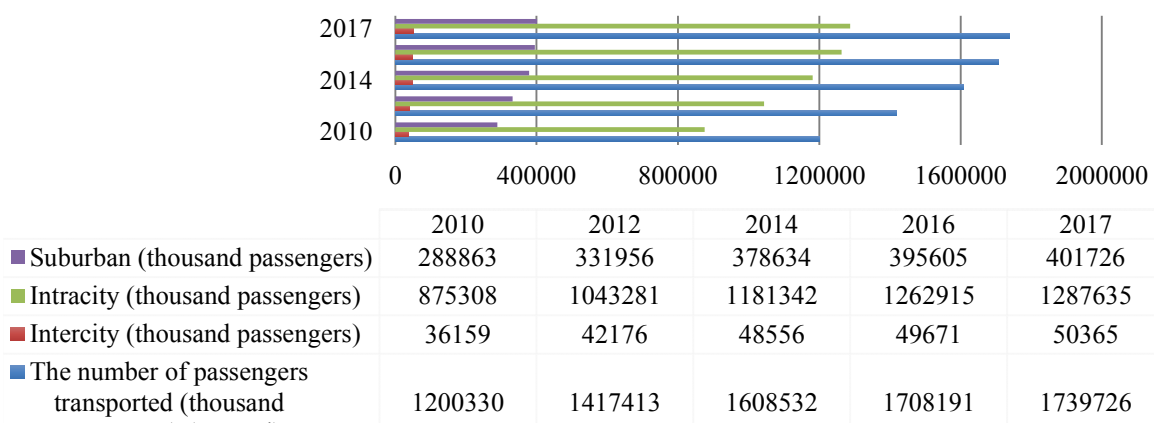
passengers) (general)

Fig. 6. Passenger transportation in Azerbaijan in 2010-2017 on car transport. Source: State Statistical Committee of the Republic of Azerbaijan. Azerbaijan Statistical Information Service. Statistics on transport sector. Baku 2018

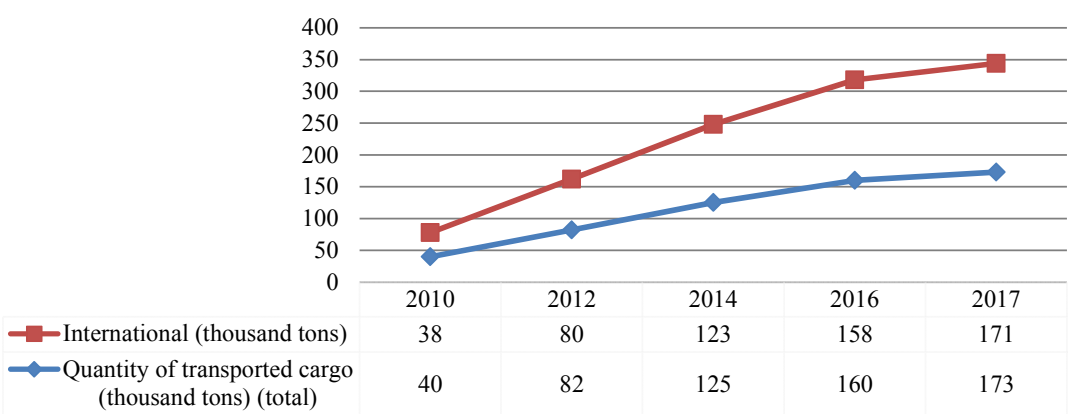

Fig. 7. Cargo transportation in Azerbaijan for 2010-2017 in air transport. Source: State Statistical Committee of the Republic of Azerbaijan. Azerbaijan Statistical Information Service. Statistics on transport sector. Baku 2018

The profit from this sector in 2017 amounted to 1.647 billion manats. The revenue from international cargo transportation has been achieved. The above-mentioned revenues make up $71.82 \%$ of the total revenue in 2017 , with 1,185 billion manats. Passenger transport revenues totaled $28.04 \%$ of the total revenue, including 462 million manats. International and local transportation of passengers were 427 million manats and 35.281 million manats respectively. This was 25.9 percent and 2.14 percent of the total revenues. Costs for cargo transportation approached to income and amounted to 1.627 billion manats. According to cargo transportation, it was 992,168 million manats and made up 61.1 percent of the total cost. The expenditures for passenger transportation amounted to 634.330 million manats and made up 38.9 percent of the total expenditures. Average monthly nominal wages in this sphere amounted to 1038.2 manats in 2017. 2,359 million passengers have been transported in 2017. Transportation of 1,770 million people here is internationally and 589,000 are for domestic transportation. The average annual number of employees increased by 12,409 in 2017 (Fig. 8) [8].

The length of the main pipelines for the year 2017 (across the country) was $5376 \mathrm{~km}$. The main oil pipelines were $1523 \mathrm{~km}$ and the main gas pipeline was $3853 \mathrm{~km}$. The Baku-Tbilisi-Ceyhan main line is $442 \mathrm{~km}$ long and Sangachal-Supsa is $456 \mathrm{~km}$ long. The Baku-Tbilisi-Erzurum gas pipeline is $442 \mathrm{~km}$. The average annual number of employees in this sector was 3136 in 2010 and increased to 3906 in 2014, but decreased by 2017 and reached 3184 workers. Average monthly nominal wages increased from 434 to 826 manats in the same period. The average monthly salary in the oil pipeline sector was 984 manats and 776 manats in the gas pipeline sector. There were 805 workers, working on oil pipelines and 2379 workers in gas pipelines. The revenues from the transportation of pipelines amounted to 1.7 billion in 2010 and 2.2 billion in 2017. It is indicated here that 1.6 billion manats through oil pipelines and 604 million manats from gas pipelines have been gained (Fig. 9) [8]. 


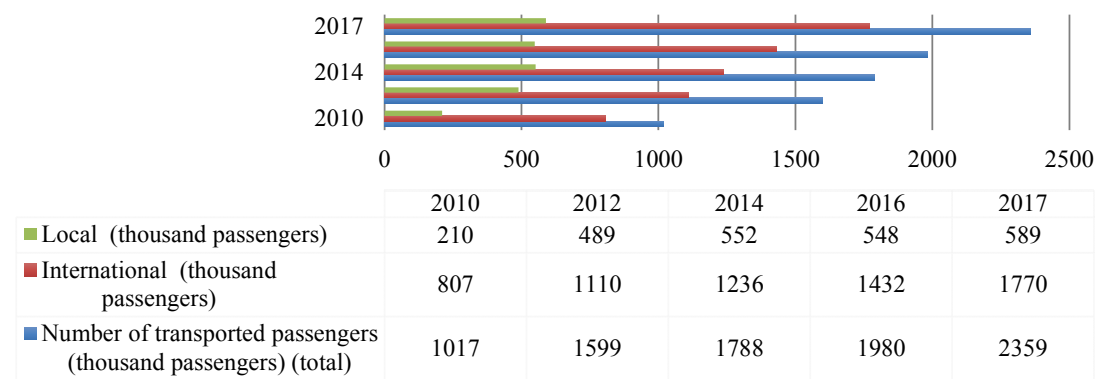

Fig. 8. Passenger transportation of air transport in Azerbaijan for 2010-2017.

Source: State Statistical Committee of the Republic of Azerbaijan. Azerbaijan Statistical Information Service. Statistics on transport sector. Baku 2018

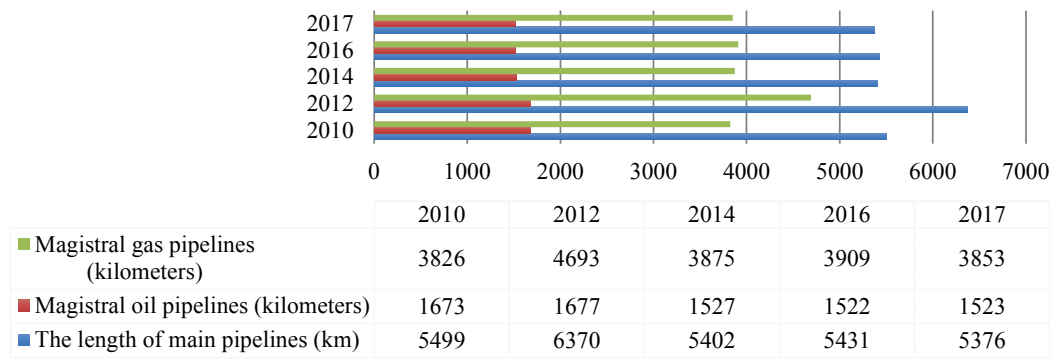

Fig. 9. Main pipelines in Azerbaijan for 2010-2017.

Source: State Statistical Committee of the Republic of Azerbaijan. Azerbaijan Statistical Information Service. Statistics on transport sector. Baku 2018

As noted, there are also many international transport corridors that give impetus to the sustainable and diversified development of the Azerbaijani economy and turn the country into an interregional transit center, which are also of great importance. We can describe these corridors as follows.

South-West Transport Corridor. Route: India - Persian Gulf - Iran - Azerbaijan Georgia - Ukraine - Europe. This corridor is designed to transport cargo between the European Union and India. The corridor from Iran, Azerbaijan, Georgia and Ukraine will reduce time losses in transportation of goods from India to Europe and back. According to preliminary estimates, cargo transportation on this corridor will be available within 7 days. The alternative route delivery time is 35-37 days [9].

East-West Transportation Corridor. Route: China - Kazakhstan - Caspian Sea - Azerbaijan - Georgia - Turkey and / or Black Sea - Europe. The Middle Corridor or the Trans-Caspian International Transport Route (TXBNM) serves to increase cargo transportation from China to Turkey and to the European Union countries and to the opposite direction. The management and development of the transport corridor are carried out by members of the Consortium. Consortium members include China Railways in China, KTZ Express in Kazakhstan, in Caspian Sea Shipping Company, Azerbaijan Railways Express in Azerbaijan, Trans-Caucasus Terminal Companies in Georgia. The Nomad Express trains, which run on this corridor, ship the cargo from China to Europe for about 10-12 days. This is one of the main advantages of the transport corridor. The cargo is transported to Europe with two corridors. One of them is via the Georgian ports of Poti and Batumi and the other is on the Baku-Tbilisi-Kars railway, which was started operating on October 30. Following the commissioning of the Baku-Tbilisi-Kars project, the transportation costs of the medium-sized corridor are significantly reduced and it serves to increase transit supplies more efficiently [10].

North-South Transport Corridor. Route: Baltic Sea - Russia - Azerbaijan - Iran - India. The corridor is mainly used for transportation from India and the Persian Gulf region to Russia, Western Europe, Baltic and Scandinavian countries. The main advantage of the North-South Corridor, 
compared to other routes, is that the transit distance and transit time is two-three times less. If the shipment is by sea over the Gulf of the Persian Gulf and the Indian Ocean, the Suez Canal, the Mediterranean Sea, the Baltic Sea to Helsinki for a period of 45 to 60 days, then the North-South Transit Corridor will last for 20-25 days. Within the framework of this international transport corridor, the work is underway to connect the railways of Azerbaijan and Iran. The railway from Azerbaijan's Astara station to Astara city of Iran has already been built. The next stage will be the construction of a 167-kilometer-long Astara-Rasht railway, complete with the full integration of Iranian and Azerbaijani railways. Once all the work is completed, the railways of the Scandinavian countries, Russia, Azerbaijan and Iran will be united into a network and a single railway from North to Iran will be formed [11].

\section{Result and Discussion}

The SWOT analysis of the country's logistics sector has been provided in the Strategic Road Map on Logistics and Trade Development in the Republic of Azerbaijan [5].

As noted on the Road Map, a number of important infrastructure projects, such as the construction of a new port complex in the country and building new rail links with neighboring countries have been implemented and there are various privilege mechanisms in the legislation. These should be regarded as strong sides in the country's logistics sector development.

It should be noted, that in Azerbaijan there is a lack of qualified personnel in logistics, not so high productivity, lack of financial resources, lack of equipment, marketing, sales and distribution services, lack of modern business models in enterprises, lack of innovative activity, there are problems such as the low shipping capacity of ships, the abundance of windy days in the Caspian Sea and the low depth of the sea. These problems are considered to be vulnerable to slow down the development of logistics in the country

At the same time, many positive moments in the development of the logistics sector in Azerbaijan can be mentioned. These include:

- Creation of a free economic zone in the new Baku International Sea Trade Port, located in Alat settlement of Garadagh district of Baku;

- Creation of logistics junction in HeydarAliyev International Airport;

- ensuring macroeconomic stability in the country;

- State support for the development of the logistics sector;

- involvement of foreign investors in supporting the projects;

- Human resources, especially the potential young generation;

- The ability of the country to be geographically advantageous and to become a regional logistics junction;

- Increasing trade and competition in the region and around the world;

- Proximity to large regional markets, continuity of infrastructure and infrastructure improvement for entrepreneurial activity;

- Launch of North-South transport corridor connecting Iran with Russia and Iran to Europe;

- Transportation of goods of Iran, India and Pakistan through Azerbaijan via the NorthSouth transport corridor to Europe and so on.

However, there are dangers in this sector as well. Some of them are the risk of stagnation in the financial markets, the probability of weakening of the investment activity as a result of the sharp decline in oil prices, the increase in the environmental protection requirements, the problem of currency exchange rate stability as one of the main factors for foreign investors, and the delay in the completion of infrastructure projects. Also, factors such as the Trans-Siberian, Trans-Siberian-Kazakhstan and maritime routes, alternating with the East-West transport corridor, connecting Europe with Central Asia and China, and the strong competition in the corridor by combining railways between Iran and Turkmenistan, still keep their relevance, and because of this we consider them development threats.

Based on the above-mentioned SWOT analysis, the Government of Azerbaijan has identified a number of strategic targets and plans to implement relevant projects. Let's look at some of these strategic targets. 
By 2020, transiting western and eastern transit lines to Azerbaijan, as well as providing regional transit cargo across Azerbaijan, it is not planning to create additional value on those cargoes. Based on the strategic goals, priorities are to be implemented using the strengths and capabilities of the country. Thus, strengthening of relevant efforts to bring the transit corridors into a competitive environment in order to transform Azerbaijan into a regional logistics junction in the long run, the organization of the free trade zone activities, including the territory of the new Baku International Sea Trade Port, located in Alat settlement of Garadagh district of Baku, the development of feasibility studies for free trade zones, increasing trade volume and achieving greater added value of transit trade for the further diversification of the Azerbaijani economy have been targeted at the 2020 strategic goal. When these strategic goals are achieved, the real GDP in Azerbaijan will increase by 2020, totaling 605 million, which is expected to increase directly by 400 million and 205 million respectively. Totally, 8000 new jobs will be created indirectly, and 10900 new jobs will be created directly. Implementation of these planned activities requires 3.160 million manats. These investments will be provided at the expense of public-private sources of financing after the technical and logistical substantiation is undertaken.

The strategic goal, which envisages the period up to 2025 , is to strengthen the automobile and rail links in order to provide a fertile integration of the Baku International Sea Trade Port to HeydarAliyev International Airport and the country's domestic trade network. In addition, in order to improve interregional relations, construction and repair of roads will be launched, as well as the construction of railways after the volume of cargo transportation will be economically viable, and the establishment of new logistics centers in the border areas for further implementation of the targets. During the implementation of these planned activities, measures will be taken to bring the country's main logistics companies to international standards in the long term, which will create conditions for the development of transport in the country, and will ultimately lead to additional direct foreign investments to Azerbaijan. To this end, international logistics companies will be accredited internationally. As a result, Azerbaijani logistics companies will be able to act as reliable companies in international markets.

The targets for the period after 2025 are intended to have a logistics junction, located at the HeydarAliyev International Airport, and a strong logistics and shopping center, located in the new Baku International Sea Trade Port complex in Alat, as well as a free trade zone.

The following targets have been set by the Azerbaijani government to achieve strategic goals:

Increasing the transit trade volume by region: 40 per cent on the Central Asia and Black Sea route; 25 per cent on Central Asia and Europe; 3 per cent on China and Europe; 40 per cent on Russia and Iran route; Getting 25 percent stake in Iran and the Black Sea route:

- Establish monitoring systems for project implementation and completion of projects;

- organization of free trade zone activities, including logistics and port services;

- Establish 5 or 6 logistics and shopping centers in Azerbaijan (four of them should be completed by 2020). The direct impact of logistics and shopping center should be 20 percent of the total regional logistics and trade interactions;

-5 percent increase in net income from air traffic operations [5].

\section{Conclusion}

Recent processes in the world have shown that it is risky for Azerbaijan, because the main source of income in the country is the oil and oil sector. From this point of view, the development of the competitive non-oil sector in the country is also important. One of these aspects is the logistics sector. As one of the priority areas for the development of the non-oil sector, the logistics sector plays a major role in promoting these sectors as an important factor in linking all the other sectors of the economy. Given the need for strengthening the logistics sector in terms of overall economic progress and the existing potential, it should be set as a goal to achieve important targets in this area.

Activities should be continued in order to make Azerbaijan an important logistics and trade hub in the region, effectively using the strategic geographical position of the country, to involve transit cargo into the transport corridors through the territory of Azerbaijan, to establish logistics 
and shopping centers in the regions, as a production and investment centers. At the same time, it is necessary to work on increasing the investment attractiveness of the country by evaluating opportunities for new businesses, employment opportunities and value added creation. Thus, the time and costs, spent on import-export operations and transportation of transit cargoes, should be optimized to ensure competitiveness of Azerbaijan in the East-West and North-South transport corridors. Border crossing procedures should be simplified and other important steps should be taken in this area and road infrastructure should be expanded along international transport corridors, reconstruction work and construction projects must be completed and adapted to international standards.

\section{References}

[1] How Logistics Improvements Affect The Economy (2018). Available at: https://www.ukessays.com/ essays/commerce/logistics-management-how-logistics-improvements-effect-the-economy-commerce-essay. php?vref=1

[2] Karayun, I., Aydin, H. I., Gulmez, M. (2012). The Role Of Logistics In Regional Development. Annals of the „Constantin Brâncuşi” University of Târgu Jiu. Economy Series, 4, 24-31.

[3] Gibbons, S., Lyytikäinen, T., Overman, H., Sanchis-Guarner, R. (2012). New Road Infrastructure: the Effects on Firms. SERC Discussion Paper 117.

[4] Nemry, F., Demirel, H. (2012). Impacts of Climate Change: A focus on road and rail transport infrastructures. European Commission Joint Research Centre. Sevilla, 89.

[5] Strategic Roadmap for Logistics and Trade Development in the Republic of Azerbaijan (2016). Baku.

[6] Where will the new metro stations be opened? (2016). Available at: https://fins.az/naqliyyat/ 896185/yeni-metro-stansiyalari-harada-achilacaq-yerlarin-siyahisi.html

[7] Samedov, M. (2018). Zheleznaya doroga zaveryaet: budet i skorost', i kachestvo. Available at: https://haqqin.az/news/126213

[8] The State Statistics Committee of the Republic of Azerbaijan. Azerbaijan Statistical Information Service. Statistics on transport sector (2018). Baku.

[9] Azerbaijan Railways CJSC. The Transportation Corridor South-West. Available at: http:// wVVw.adyexpress.az/en-uk/transportation-corridors/the-transportation-corridor-south-west

[10] Azerbaijan Railways CJSC. The Transportation Corridor East-West. Available at: http:// wVVw.adyexpress.az/en-uk/transportation-corridors/the-transportation-corridor-east-west

[11] Azerbaijan Railways CJSC. The Transportation Corridor North-South. Available at: http:// wVvw.adyexpress.az/en-uk/transportation-corridors/the-transportation-corridor-north-south 